BIOTROPIA NO. 25, $2005: 11-21$

\title{
IN VITRO CONSERVATION OF COCONUT (Cocos nucifera L.) EMBRYOS IN CULTURE MEDIA
}

\author{
SUKENDAH $^{1}$ and MA L. O. CEDO ${ }^{2}$ \\ ${ }^{1}$ Dept. of Agronomy, Faculty of Agriculture, Pembangunan Nasional "Veteran” University, \\ Surabaya, Indonesia \\ ${ }^{2}$ Assistant Professor, Dept. of Horticulture, UPLB, Laguna 4031, \\ Los Baños, Philippines
}

\begin{abstract}
The possibility of delaying the germination of mature coconut embryos in vitro for medium-term conservation of coconut was investigated. Embryos of coconut was stored in sugar free, full-strength and half-strength MS media for 3 months with minimal loss in viability. Germinability of embryos decreased with prolonged storage. At the end of 9-month storage period, embryos kept in full-strength media were all non-germinable, while those stored in half-strength media still gave $15 \%$ germination. Addition of mannitol up to $0.3 \mathrm{M}$ did show any significant effect on germination of embryos stored for 3 months. However, longer period of storage helps to a certain extent in the preservation of embryo viability. The presence of mannitol in the storage medium also induced morphological abnormalities in seedlings derived subsequently from the stored embryos. Mannitol at $0.4 \mathrm{M}$ was totally deleterious to the embryo. Significance of these findings on coconut genetic resources conservation are discussed.
\end{abstract}

Keywords: In vitro conservation/Coconut embryo.

\section{INTRODUCTION}

The safe conservation of genetic resources of coconut is faced with various problems. Coconut is a species with a truly recalcitrant seed which has no dormancy (Engelmann et al. 1995). Because of this characteristic, there is no possibility of storing it ex situ even for short periods of time. Genetic resource collections (germplasm) are conserved as special field genebanks (living plants) in national or regional centers.

Field genebanking, however, run the risk of being damaged by natural disasters, pests and diseases. It also requires more space. Moreover, many sources of plant genetic materials (Indonesia, the Pacific, and Philippines) are still almost unexplored, and the small proportion of coconut germplasm currently available in existing field collections and certain accessions are now in danger of dying. The in vitro technique addresses all these concerns. It offers the possibility of providing duplicate, healthy collections for storage and use with less space. Since vegetative propagation of coconut is as yet not feasible, embryo culture technique is a promising alternative.

Coconut embryo culture protocols are now available in the literature (Batugal and Engelmann 1998). In all these protocols, embryo germination commences soon after the embryos are placed in the culture medium. Subsequently, fully developed seedlings ready for acclimatization may be obtained within 5-7 months. For in vitro conservation, such quick growth response to the medium is not desired. Thus, efforts 
are now focussed on modifying the medium and other culture conditions in order to delay the germination while at the same time preserving the germination potential of the embryos during storage.

Techniques which can be used to maintain collection in delaying the embryo germination are: the use of reduced temperature, minimized light, and modifications in media. Ashmore (1997) was able to store sugarcane shoots at $18^{\circ} \mathrm{C}$ on reduced mineral salts, and banana shoots at $16^{\circ} \mathrm{C}$ in the presence of plant growth subtances. Chatty and Tissouni (1999) showed that the suitable temperature for major palm species is about $25^{\circ} \mathrm{C}$, whereas lack of germination was observed at the extreme temperature of $5^{\circ} \mathrm{C}$. The American palm germinated better at temperatures ranging from $25^{\circ} \mathrm{C}$ to $35^{\circ} \mathrm{C}$, but did not germinate at $15^{\circ} \mathrm{C}$. Meanwhile, $\mathrm{Ng}$ and $\mathrm{Ng}$ (1991) reported to slow down the growth rate, cultures are basically incubated under reduced light intensity or total darkness in conjunction with low incubation temperature. However, the modification of temperature and/or light to preserve cultures required a high cost because of electricity and equipment.

$\mathrm{Ng}$ and $\mathrm{Ng}$ (1991) suggested that an alternative approach to retard growth was to use a reduced-growth medium. Recent publications on slow-growth media indicate that a variety of techniques are still being utilized, such as the reducing concentration of mineral salt, increasing, decreasing or eliminating sucrose, adding mannitol or sorbitol and growth retardant to the culture medium ( $\mathrm{Ng}$ and $\mathrm{Ng}$ 1991). One of the advantages of this method is that the modification of the culture medium requires no special equipment.

Preliminary studies on storage media conducted by Assy-Bah and Engelmann (1993) have indicated that embryos of coconut can be stored for 6 months on a medium devoid of sucrose and containing $2 \mathrm{~g} / \mathrm{l}$ activated charcoal with eventual germination of stored embryos at 100\%. Related study done by Damasco (2000) on Tagnanan Tall showed that ABA and mannitol at low concentrations (0.05 to $0.1 \mathrm{M})$ might not be effective to inhibit growth in culture. However, high concentration of mannitol $(0.2$ and $0.3 \mathrm{M})$ significantly reduced percent germination and subsequent growth of germinated embryos. In this report, results on the use of reduced-nutrient media and mannitol for coconut embryo storage are presented.

\section{MATERIALS AND METHODS}

\section{Collection, Sterilization, and Excision of Embryos}

Mature (11-12 months) coconut palm variety 'Tagnanan Tall' were collected from the Philippine Coconut Authority Zamboanga Research Center. A cylinder of endosperm embedding the embryo was extracted from each nut using a 2-cmdiameter cork borer. The endosperm cylinders were washed in 95\% ethanol (1-2 minutes) then sterilized in $100 \%$ commercial bleach (5-6\% sodium hypochlorite) for 20 minutes. 
Under aseptic condition, the embryos were excised from the solid endosperm cylinders, then sterilized in two changes of $10 \%$ commercial bleach for 5 minutes at each time and finally rinsed three times with sterile distilled water. Sterilized embryos were transferred to a sterile flask containing sterile distilled water for size selection. The same size embryos $( \pm 1 \mathrm{~cm})$ were then inoculated singly onto liquid storage medium according to the treatments.

\section{Culture Media and Arrangement of Treatments}

The composition of the storage medium used in the present experiment was that of Assy-Bah (1986), at full-strength or half-strength. The medium contained activated charcoal and had no sucrose. After the required period of storage $(3,6$, and 9 months), embryos were germinated following the embryo culture protocol of the University of the Philippines at Los Baňos or UPLB (Batugal and Engelmann 1998).

The experiment was conducted by culturing the embryos in test tubes containing $10 \mathrm{ml}$ of full-strength or half-strength MS media without or with mannitol at $0.10 \mathrm{M}, 0.2 \mathrm{M}, 0.30 \mathrm{M}$, or $0.4 \mathrm{M}$. Each treatment was replicated three times, each consisting of 35 embryos. The cultures were randomized and incubated in a dark room with temperature maintained at $25^{\circ} \mathrm{C}$.

\section{Observation of Embryos}

Viability of embryos was evaluated based on the following parameters: Length of embryos, measured every 2 months since embryos have been incubated; Percent germination, it was done after the embryos have been preserved for 3, 6, and 9 months of storage. The stored embryos from the experiment were transferred to the germination medium described in the UPLB protocol; Normal and abnormal seedlings, observed 3 months after embryos have been transferred to the germination medium. Seedlings which showed well-developed roots \& shoots were considered normal, and seedlings with no shoot, no root or stunted seedlings as abnormal seedling. Data were collected based on: a) Percent normal seedlings and abnormal seedlings, and b) Morphological features, observed by taken their photograph.

Observations of shoot length, number of leaves, leaf width, leaf length, length of primary root, and number of adventitious roots for normal seedlings were done 5 months after the embryos have been transferred to the germination medium.

\section{RESULTS AND DISCUSSIONS}

Coconut embryos that preserved in full-strength or half-strength MS basal medium significantly increased in length even up to $6^{\text {th }}$ month of storage. In overall, embryos maintained in half-strength media were significantly longer than embryos in the full-strength media (Table 1). Previous studies on reducing the mineral salt concentration showed that the cultures in general grow slowly or not at all (Ashmore 
1997). Apparently the coconut embryos did not have the same response. No further study has reported on the response of coconut embryos treated in low-salt medium. Interestingly, at the end of each storage period, it was noted that the final volumes of the spent half-strength media were lower than those of the full-strength media (data not presented). This supports the view that greater growth (in length) of embryos in the half-strength media could have resulted from greater nutrient and water uptake by embryos in those media.

By contrast, addition of mannitol to the storage medium tended to inhibit elongation of embryos during storage. Increasing amounts of mannitol $(0.1 \mathrm{M}$ to 0.4 M) increasingly reduced the final lengths of the embryos, particularly during the first two months of storage (Table 1). Beyond 6 months of storage, no significant difference on final length among embryos was noted.

Table 1. Effects of level of nutrients and concentration of mannitol on elongation growth of coconut embryo during storage

\begin{tabular}{lccc}
\hline \hline \multirow{2}{*}{ Treatments } & \multicolumn{3}{c}{ Period of Storage (month) } \\
\cline { 2 - 4 } & 2 & 4 & 6 \\
\hline & & Final length of embryo (mm) \\
Level of nutrients: & & & \\
Full-strength & $9.76 \mathrm{~b}^{*}$ & $11.01 \mathrm{~ns}$ & $11.33 \mathrm{~ns}$ \\
Half-strength & $10.37 \mathrm{a}$ & 11.56 & 11.71 \\
Concentration of & & & \\
Mannitol (M): & & & $12.27 \mathrm{~ns}$ \\
0.0 & $10.55 \mathrm{a}$ & $11.85 \mathrm{~ns}$ & 12.23 \\
0.1 & $10.65 \mathrm{a}$ & 11.83 & 11.50 \\
0.2 & $10.17 \mathrm{a}$ & 11.28 & 11.45 \\
0.3 & $9.58 \mathrm{ab}$ & 11.37 & 10.15 \\
0.4 & $9.38 \mathrm{~b}$ & 10.12 & \\
\hline
\end{tabular}

* Means followed by the same letter in a column for each factor are not significantly different from each other using LSD at 5\% level of significance

When the stored coconut embryos are placed in a germination medium such as Y3 (Eeuwens medium), they would start germinating or may exhibit a slight increase in size but still remain ungerminated or the embryos may take a deteriorative path and eventually dies. Table 2 shows that storing coconut embryos for 3 months in the modified MS medium, either at full-strength or half-strength, resulted in significant $10-30 \%$ reduction in percent germination. Prolonging the storage period to 6 months reduced even further the germination to $10-30 \%$ in five of the treatments and to zero (no germination) in the other five treatments. With 9 months of storage all embryos kept in full-strength media become non-germinable, while those kept in half-strength media containing low amounts of mannitol showed $13-20 \%$ germination. Mannitol when added to half-strength (but not to full strength) 
Control of culture media for in vitro conservation of coconut - Sukendah and Ma L.O. Cedo

Table 2. Percent germination of stored embryos observed 2 months after transfer to the modified Y3 germination medium

\begin{tabular}{|c|c|c|c|c|}
\hline \multirow{2}{*}{$\begin{array}{l}\text { Level of } \\
\text { Nutrients }\end{array}$} & \multirow{2}{*}{$\begin{array}{c}\text { Mannitol } \\
\text { Concentration } \\
\text { (M) }\end{array}$} & \multicolumn{3}{|c|}{ Period of Storage (month) } \\
\hline & & 3 & 6 & 9 \\
\hline \multirow[t]{5}{*}{ Full-strength } & 0.0 & $80.00 \mathrm{bc}^{*}$ & $30.00 \mathrm{~b}$ & $00.00 \mathrm{c}$ \\
\hline & 0.1 & $70.00 \mathrm{c}$ & $00.00 \mathrm{~d}$ & $00.00 \mathrm{c}$ \\
\hline & 0.2 & $80.00 \mathrm{bc}$ & $20.00 \mathrm{cb}$ & $00.00 \mathrm{c}$ \\
\hline & 0.3 & $90.00 \mathrm{ab}$ & $00.00 \mathrm{~d}$ & $00.06 \mathrm{c}$ \\
\hline & 0.4 & $20.00 \mathrm{e}$ & $00.00 \mathrm{~d}$ & $00.00 \mathrm{c}$ \\
\hline \multirow[t]{5}{*}{ Half-strength: } & 0.0 & $100.00 \mathrm{a}$ & $00.00 \mathrm{~d}$ & $00.00 \mathrm{c}$ \\
\hline & 0.1 & $80.00 \mathrm{bc}$ & $20.00 \mathrm{cb}$ & $20.00 \mathrm{~b}$ \\
\hline & 0.2 & $100.00 \mathrm{a}$ & $30.00 \mathrm{~b}$ & $20.00 \mathrm{~b}$ \\
\hline & 0.3 & $90.00 \mathrm{ab}$ & $10.00 \mathrm{~cd}$ & $13.33 \mathrm{~b}$ \\
\hline & 0.4 & $40.00 \mathrm{~d}$ & $00.00 \mathrm{~d}$ & $00.00 \mathrm{c}$ \\
\hline Unstored embryos & & $100.00 \mathrm{a}$ & $100.00 \mathrm{a}$ & $100.00 \mathrm{a}$ \\
\hline
\end{tabular}

* Means followed by the same letter in a column are not significantly different from each other using DMRT at $5 \%$ level of significance.

media up to $0.3 \mathrm{M}$ appeared to help preserve the viability of the stored embryos. It is possible that the hypertonic condition created by the addition of mannitol at this level could have helped maintain membrane integrity, thus prevent rapid cell death which otherwise occurs in untreated coconut embryos during prolonged storage. Gomez et al. (1995) reported that mannitol significantly prevented EP-catalyzed hydrolysis of 40 and $50 \mathrm{kDa}$ polypeptides. EP (endopeptidase) is a monomeric enzyme (Gomez et al. 1994) that has an important role in the digestion of cell wall protein. However, addition of high mannitol concentration $(0.4 \mathrm{M})$ significantly inhibited the germination of embryos.

After the required storage period, embryos were transferred to the Y3 germination medium. Although high percentage of the stored embryos exhibited the early signs of germination and they were considered germinated (Table 2), many of these embryos did not develop into normal seedlings. In fact, some $10-70 \%$ of them showed abnormal growth such as produced well-developed roots but without shoots or well-developed shoot but little elongation of roots or stunted seedling even up to the third month after transfer to the Y3 medium (Table 3 \& Fig. 1).

Of the remaining embryos, normal seedlings were obtained from those stored in media without mannitol or with mannitol at $0.1 \mathrm{M}$ (Fig. 2). The presence of higher levels of mannitol $(0.2$ and $0.3 \mathrm{M})$ in the storage medium seemed to have inhibited seedling development. Seedlings tended to produce shorter shoots whether stored in full-strength or half-strength media. With $0.4 \mathrm{M}$ mannitol, development of shoot and root totally failed (Table 4). Several authors have reported similar inhibitory effect of mannitol on growth of several crops (Ashmore 1997; Babu et al. 1999; and Damasco 2000). 
BIOTROPIA NO. 25, 2005

Table 3. Percentage of normal and abnormal seedlings developed from embryos stored for 3 months in full and half-strength media with or without mannitol

\begin{tabular}{|c|c|c|c|c|c|c|c|}
\hline \multirow{2}{*}{$\begin{array}{l}\text { Mannitol } \\
\text { Concen- } \\
\text { tration } \\
\text { (M) }\end{array}$} & \multirow{2}{*}{$\begin{array}{c}\text { Total } \\
\text { Number } \\
\text { of } \\
\text { Embryos } \\
\text { cultured } \\
\end{array}$} & \multirow{2}{*}{$\begin{array}{c}\text { Un- } \\
\text { germinated } \\
\text { Embryos }\end{array}$} & \multirow{2}{*}{$\begin{array}{l}\text { Normal } \\
\text { Seedling }\end{array}$} & \multicolumn{3}{|c|}{ Abnormal Seedlings } & \multirow{2}{*}{$\begin{array}{c}\text { Total } \\
\text { Abnormal } \\
\text { Seedlings } \\
(\mathrm{a}+\mathrm{b}+\mathrm{c})\end{array}$} \\
\hline & & & & $\begin{array}{c}\text { No shoot } \\
\text { (a) }\end{array}$ & $\begin{array}{l}\text { No root } \\
\text { (b) }\end{array}$ & $\begin{array}{l}\text { Stunted } \\
\text { (c) }\end{array}$ & \\
\hline \multicolumn{8}{|l|}{$\begin{array}{l}\text { Full- } \\
\text { strength } \\
\text { Medium: }\end{array}$} \\
\hline 0.0 & 10 & 20 & 80 & 0.0 & 0.0 & 0.0 & 0.0 \\
\hline 0.1 & 10 & 30 & 70 & 0.0 & 0.0 & 0.0 & 0.0 \\
\hline 0.2 & 10 & 20 & 50 & 20 & 0.0 & 10 & 30 \\
\hline 0.3 & 10 & 10 & 30 & 30 & 10 & 20 & 60 \\
\hline 0.4 & 10 & 80 & 0.0 & 20 & 0.0 & 0.0 & 20 \\
\hline \multicolumn{8}{|l|}{$\begin{array}{l}\text { Half- } \\
\text { strength } \\
\text { Medium: }\end{array}$} \\
\hline 0.0 & 10 & 0 & 80 & 0.0 & 10 & 10 & 20 \\
\hline 0.1 & 10 & 20 & 70 & 0.0 & 0.0 & 10 & 10 \\
\hline 0.2 & 10 & 0 & 60 & 20 & 0.0 & 20 & 40 \\
\hline 0.3 & 10 & 10 & 20 & 50 & 0.0 & 20 & 70 \\
\hline 0.4 & 10 & 60 & 0.0 & 30 & 0.0 & 10 & 40 \\
\hline
\end{tabular}
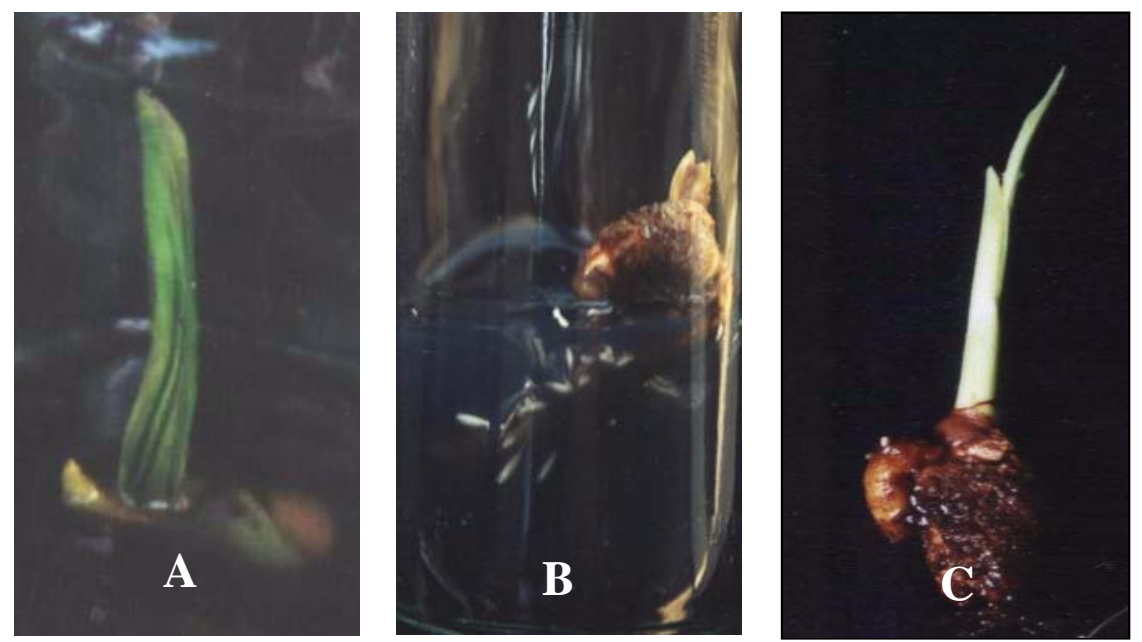

Figure 1. A. Abnormal seedling with stunted growth; B. Abnormal seedling with extensive root system but without shoot; C. Abnormal seedling with two sword leaves and an enlarged base but without fully formed root 
Control of culture media for in vitro conservation of coconut - Sukendah and Ma L.O. Cedo

Table 4. Shoot and root development of seedling grown from embryos stored for 3 months in half- and full-strength MS medium with various concentration of mannitol

\begin{tabular}{cllllll}
\hline \hline $\begin{array}{c}\text { Concentrations } \\
\text { mannitol } \\
(\mathrm{M})\end{array}$ & $\begin{array}{c}\text { Shoot } \\
\text { length } \\
(\mathrm{cm})\end{array}$ & $\begin{array}{c}\text { Total no. of } \\
\text { leaves/plant }\end{array}$ & $\begin{array}{c}\text { Average } \\
\text { leaf width } \\
(\mathrm{cm})\end{array}$ & $\begin{array}{c}\text { Average } \\
\text { leaf } \\
\text { length } \\
(\mathrm{cm})\end{array}$ & $\begin{array}{c}\text { Length of } \\
\text { primary } \\
\text { root } \\
(\mathrm{cm})\end{array}$ & $\begin{array}{c}\text { No. of } \\
\text { adventitious } \\
\text { root }\end{array}$ \\
\hline $\begin{array}{c}\text { Full-strength } \\
\text { medium: }\end{array}$ & & & & & \\
0.0 & $11.23 \mathrm{~ns}$ & $2.50 \mathrm{~ns}$ & $1.47 \mathrm{~ns}$ & $7.20 \mathrm{~ns}$ & $8.93 \mathrm{~ns}$ & $2.00 \mathrm{~ns}$ \\
0.1 & 10.58 & 2.17 & 1.43 & 8.08 & 8.10 & 1.17 \\
0.2 & 8.05 & 2.00 & 1.13 & 6.18 & 5.88 & 1.25 \\
0.3 & 8.15 & 3.00 & 1.20 & 6.92 & 6.60 & 2.00 \\
0.4 & $0.00 \#$ & $0.00 \#$ & $0.00 \#$ & $0.00 \#$ & $0.00 \#$ & $0.00 \#$ \\
Half-strength & & & & & & \\
medium: & & & & & & \\
0.0 & $11.48 \mathrm{~ns}$ & $2.50 \mathrm{~ns}$ & $1.40 \mathrm{~ns}$ & $8.33 \mathrm{~ns}$ & $6.08 \mathrm{~ns}$ & $1.00 \mathrm{~ns}$ \\
0.1 & 10.02 & 2.33 & 1.50 & 6.93 & 5.13 & 1.17 \\
0.2 & 10.90 & 2.50 & 2.08 & 6.68 & 6.25 & 1.50 \\
0.3 & 6.80 & 1.00 & 0.40 & 2.40 & 2.40 & 1.00 \\
0.4 & $0.00 \#$ & $0.00 \#$ & $0.00 \#$ & $0.00 \#$ & $0.00 \#$ & $0.00 \#$ \\
Unstored & $17.66 *$ & 3.00 & $3.03 * *$ & 10.06 & 10.57 & 1.20 \\
embryos & & & & & & \\
\hline
\end{tabular}

$\mathrm{ns}=$ not significantly different among the treatments in the same column

* = significantly different from stored embryos in the same column

** = highly significantly different from stored embryos in the same column

$\#=$ embryos remained germinated

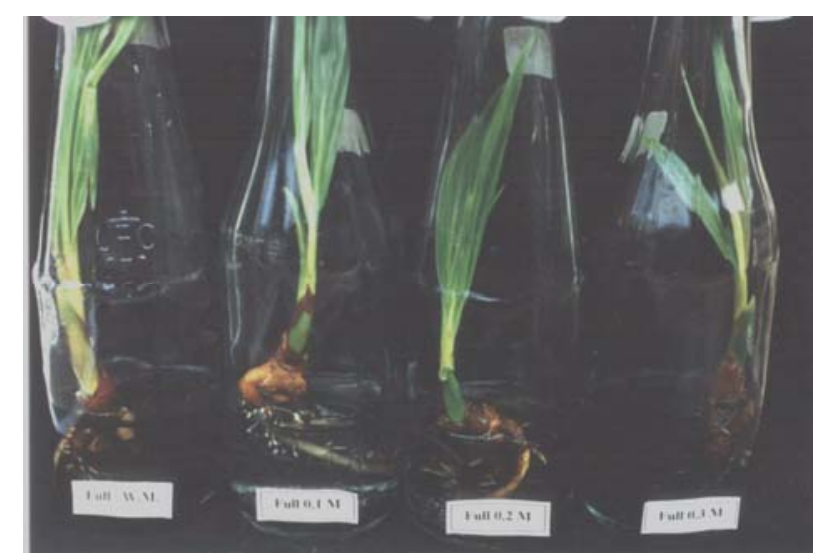

Figure 2. Normal five-month-old seedlings in full-strength medium with various concentrations of mannitol 
Inhibitory effect of osmotically active agents such as mannitol at high level has appeared during the storing period of embryos (Table 1). These embryos, then were not able to germinate even though supported by enough nutrient. Mannitol is a metabolically inactive sugar alcohol (Dodd et al. 1991). It is one of compatible solutes that can decrease plant water potential by osmotic adjustment (the accumulation of compatible solutes that promotes acclimation to dry) (Buchanan et al. 2005). The large amount of mannitol in the cell could result in the increase of the osmotic pressure of the medium drastically. A high osmotic potential in the external medium can induce the protoplast to lose water, causing the cells to become plasmolyzed. If kept in this medium for extended period, it can cause cells to become permanently damaged. Study on leaf disks of maize under hyperosmotic condition by Del Longo (1993) revealed the cellular damage in both the sensitive and the resistant maize line. Damage as indicated by, for example, the extension of lipid peroxidation, the destruction of chlorophyll and carotenoids, the decrease in levels of protein sulfhydryl groups and the leakage of electrolytes from cells was apparent in leaf disks as a consequence of the applied stresses $(0.5 \mathrm{M}$ mannitol).

It should be mentioned that the stored embryos were not washed off before they were transferred to the germination media. So that the mannitol in the storage media was carried over to the new media. This could have caused the abnormal growth of the seedling. The washing step was not done, however to avoid the removal of important metabolites from possibly already leaky cells as suggested by Withers (1986; cited by Benson 1990).

Microscopic observations of the paraffin sections of the embryos showed that high mannitol concentration caused plasmolysis of cells in the region of the apical meristem, which could have led to damage of shoot or root development (Fig. 3). Evidence from some researches showed that the damage occurred on the hypocotyls

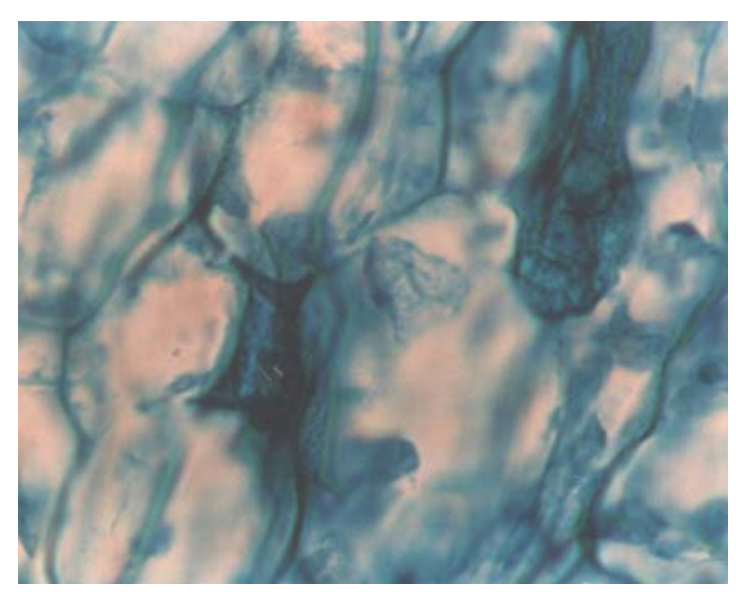

Figure 3. Plasmolyzed cells in $0.3 \mathrm{M}$ mannitol medium 
or in a critical number of cells of the axis would produce abnormal seedling or the germination would be retarded. Thus, the symptoms of slow growth, abnormal growth, or no growth could result from fundamental changes in membranes and macromolecules.

The results showed that delaying the germination of coconut embryos of the variety "Tagnanan" was effective for up to 3-month-storage period. After 3 months, the deterioration of embryos occurred very fast. By the end of 9 months, most of the embryos showed significant loss in viability. However, some embryos still showed viability potential after 9 months of storage (indicated by percent germination of about $20-30 \%$ ). Clearly, there is still a need for further studies on the culture media of coconut embryos to increase the viability and germinability of embryos longer than 3 months period of storage.

Addition of mannitol at a low concentration, lower than $0.2 \mathrm{M}$, gave a high germination rate (70-100\%) and relatively high percentage of normal seedlings (50$60 \%$ ), both in the full-strength and half-strength media free of sucrose. Damasco (2000) reported that addition of mannitol at 0.05 to $0.1 \mathrm{M}$ to the medium containing high level of sucrose $(60 \mathrm{~g} / \mathrm{l})$ induced germination and growth of coconut embryos of the variety 'Tagnanan' with the same germination rate as the control treatment. It appeared that mannitol was not effective in delaying germination. Since the present study was able to delay the germination up to 3 months and maintain high viability, further studies using other substances which could delay germination should be done. Sucrose analysis showed that coconut embryo contains very low amount of sucrose, only $42.49 \mathrm{mg}$ per $100 \mathrm{~g}$ dry weight. Apparently, addition of some amount of sugar in the storage medium may still be important.

The study indicated that it is possible to prolong the inactive metabolic phase of coconut embryos before the active germination phase for at least 3 months by controlling the culture medium. Technique of delaying the germination may be used as a complementary conservation strategy of coconut germplasm. This technique may have a role in one or more activities in the conservation-use cycle such as in in vitro collecting, in vitro exchange and distribution of coconut germplasm, and in vitro conservation.

\section{CONCLUSIONS}

The overall results indicate that it is possible to delay the germination of coconut embryo in vitro for up to 3 months without loss in viability.

MS medium at half-strength was found to be a better medium for embryo storage than the full-strength medium. Addition of mannitol at low concentration ( $0.2 \mathrm{M}$ or lower) did not have any significant effect on storage. However, with $0.3 \mathrm{M}$ or higher concentration of mannitol, the germination fell drastically to $30 \%$. Furthermore, high concentration of mannitol induced abnormality in the resulting seedlings (formation of shoot without root, root without shoot, and stunting). 


\section{ACKNOWLEDGMENTS}

The author would like to express her sincere gratitude to SEARCA and IPGRI for the financial support to endure this study. She is also deeply grateful to the Director and staff of Department of Horticulture, UPLB, Philippines for the assistance and facilities and also to Mr. Carlos B. Carpio, Deputy Administrator, ARDB, PCA for the supply of the coconut embryos.

\section{REFERENCES}

ASHMORE, S.E. 1997. Status report on the development and application of in vitro techniques for the conservation use of plant genetic resources. IPGRI. Rome. 67p.

ASSY-BAH, B. 1986. Culture in vitro d'embryos zygotiques de cocotiers. Oleagineux 41:321-328.

ASSY-BAH, B. and F. ENGELMANN. 1993. Medium-term conservation of mature embryos of coconut (Cocos nucifera L.). Plant, Cell, Tissue and Organ Cult. 33:19-24.

BABU, K.N., S.P. GEETHA, D. MINOO, P.N. RAVINDRAN and K.V. PETER. 1999. In vitro conservation of cardamom (Elettaria cardamomum Maton) germplasm. Plant Genetic Resources Newsletter. 119:41-45.

BATUGAL, P.A and F. ENGELMANN. 1998. Coconut Embryo In Vitro Culture. Proceedings of the First Workshop on Embryo Culture 27 -31 October 1997 Banao, Guinobatan, Albay, Philippines.

BENSON, E.E. 1990. Free radical damage in stored plant germplasm. International Board for Plant Genetic Resources. Rome.

BUCHANAN, B.B., W. GRUSSEN, and R.L. JONES. 2005. Biochemistry and Moleculer Biology of Plants. Chapter 22: Responses to abiotic stresses. ASPB (American Society of Plant Biologists). New York.

CHATTY, Y. and T. TISSOUNI. 1999. Efect of temperature on germination of ornamental palm tees in Tunisia. In: Ruano,M. C. (ed.). Proc. Of the $2^{\text {nd }}$ Int. Symp. On Ornamental Palms and Other Monocots from the Tropics. Acta Hortic. 486, ISHS.

DAMASCO, O.P. 2000. Utilization of embryo culture technology for gemplasm conservation: Development of medium term conservation for coconut zygotic embryos. Paper report of the $2^{\text {nd }}$ Inter. Coconut Embryo Culture Workshop, Merida, 20-23 March, 2000. Mexico.

DEL LONGO, O.T., C.A. GONZALEZ, G.M. PASTORI, and V.S. TRIPPI. 1993. Antioxidant defences under hyperoxygenic and hyperosmotic conditions in leaves of two lines of maize with differential sensitivity to drought. Plant Cell Physiol. 34 (7): 1023-1028.

DODDS, J.H., Z. HUAMAN and R. LIZARRAGA. 1991. Potato germplasm conservation. In: Dodds, J.H. (ed.). In vitro Methods for Conservation of Plant Genetic Resources, Chapman and Hall. London. p. 93-109

ENGELMANN, F., B. ASSAY-BAH, S. BAGNIOL, D. DUMET, and N. MICHAUX-FERRIERE. 1995. Cryopreservation of date palm, oil palm, and coconut. In: Bajaj, Y.P.S. (ed.).Biotecnology in Agriculture and Forestry. Springer-Verlag, Berlin. p. 148-167. 
Control of culture media for in vitro conservation of coconut - Sukendah and Ma L.O. Cedo

GOMEZ, L.D., L.M. CASANO, M.ROUBY, M.S. BUCKERIDGE, and V.S. TRIPPI. 1994. Proteolytic activity associated with cell wall. Isolation and partial characterization of a protease from the extracellular fluid of bean hypocotyls. Agriscientia. 11:3-11.

GOMEZ, L.D., L.M. CASANO, and V.S. TRIPPI. 1995. Effect of hydrogen peroxide on degradation of cell wall associated proteins in growing bean hypocotyls. Plant Cell Physiol. 36 (7):1259-1264.

NG, N.Q. and S.Y.C. NG. 1991. Reduced-growth storage of germplasm. In: Dodds, J.H. (ed.). In vitro Methods for Conservation of Plant Genetic Resourcess. Chapman and Hall. London. p. 11-40. 